International Journal of Agriculture, Environment and Bioresearch

Vol. 06, No. 02; 2021

ISSN: $2456-8643$

\title{
HEMATOLOGICAL PROFILE OF BROILERS AND LOCAL CHICKENSIN KORHOGO, COTE D'IVOIRE
}

\author{
KOKORE Angoua Baudouin ${ }^{1}$, KAMAGATE Soualio1, BLEYERE Nahounou Mathieu ${ }^{2}$ and YAPO Angoue \\ Paul $^{2}$ \\ ${ }^{1}$ Department of Animal Biology, Peleforo Gon Coulibaly University of Korhogo, BP 1328 Korhogo,Côte d'Ivoire, \\ ${ }^{2}$ Laboratory of Physiology Pharmacology and Pharmacopoeia, Nangui Abrogoua University, 02 BP 801 Abidjan 02, \\ Côte d'Ivoire
}

https://doi.org/10.35410/IJAEB.2021.5618

\begin{abstract}
The poultry industry is faced with many constraints, including the lack of data on local biological blood parameters. These parameters are indicative of the breeding, feeding, environmental and even genetic conditions on which the production and welfare of the animals strongly depend. The objective of the work is to explore the hematological parameters of broilers and local chickens for consumption in the city of Korhogo.To do this, a venous blood sample was taken from 64 chickens including 32 local chickens and 32 apparently healthy broilers for a blood count. The means of hematological parameters in broilers, except PCV, white blood cells and eosinophils, and those in local chickens, except MCHC and eosinophils, are within the ranges of the reference values. The mean value of red blood cell, hemoglobin and PCV of broilers and hemoglobin and MCHC values from local chickens were significantly higher in males than in females. The percentage of local chickens with anemia was $28.13 \%$ compared to $87.50 \%$ in broilers. Both groups of chickens showed hyperleukocytosis and heterophilia. Some parameters are within the reference ranges and others are not. They are generally higher in males than in females. Similarly, they are higher in broilers than in local chickens.
\end{abstract}

Keywords: Broilers, Hematological Parameters, Local Chickens, Korhogo, Côte d'Ivoire.

\section{INTRODUCTION}

The importance of poultry farming in the daily lives of people in rural areas is well established [1]. Indeed, poultry provides people with company, food and a major source of protein in their diet [2]. Poultry farming plays a very important role in the development of a nation for both nutritional and economic reasons in many countries around the world [3]. Among poultry, chickens are important farm animal species in almost all countries in the world. It is an important source of animal protein and can be raised in situations where food and shelter resources are limited [4]. In Côte d'Ivoire, traditional poultry farming provides about $70 \%$ of the population's poultry production [5]. However, the poultry industry is faced with many constraints, including the lack of data on local biological blood parameters. Indeed, these parameters are indicative of the breeding, feeding, environmental and even genetic conditions on which the production and welfare of the animals strongly depend [6].Furthermore, these blood parameters provide valuable information in animal health. In addition, it reveals the nutritional status of the individual and 
Vol. 06, No. 02; 2021

ISSN: $2456-8643$

allows monitoring of these states in animal experiments [7, 8]. Unfortunately, the haematological profile of these parameters is little exploited in avian medicine [9]. Yet, clinical chemistry analyses can aid in the rapid diagnosis of poultry diseases and the determination of etiology and can facilitate accurate treatment and prevention [10]. In addition to that, the clinical signs of illness in birds are frequently subtle, clinical chemistry is necessary to evaluate cellular changes [11]. For proper management of poultry farms, feeding, breeding, disease prevention and treatment, it is desirable to know the normal physiological values under local conditions[12]. In the specific case of Côte d'Ivoire, studies on biological reference blood parameters, particularly hematological parameters in chickens, are practically non-existent. The question is whether the hematological parameters of broilers and local chickens are in conformity with international standards. The aim of this study is to explore the hematological parameters of broilers and local chickens intended for consumption in the city of Korhogo.

\section{MATERIELS AND METHODS}

\subsection{Experimental Site and Birds}

The experiment was carried out from December 2020 to February 2021 in the department of Korhogo situated between $5^{\circ} 16$ and $6^{\circ} 16$ of longitude West, and at latitude $8^{\circ} 32$ and $10^{\circ} 20$ Northin the northern Côte d'Ivoire. A total of 64 chickens, including 32 local chickens (22 males and 10 females) and 32 broilers (11 males and 21 females) of different ages and apparent health, were selected for the study. The average age of the local chickens was $31 \pm 9.2$ weeks and the broilers $5.4 \pm 0.46$ weeks. This is a descriptive cross-sectional study in chickens intended for consumption at the poultry market in Korhogo.

\subsection{Collection and analysis of blood sample}

In each bird, a venous blood sample is taken from the jugular vein in tubes containing an anticoagulant, Ethyl Diamine Tetra Acetic (EDTA) in the morning between 7:00 and 9:00 am. These blood samples, placed in a cooler with ice, are transported before 12 o'clock on the day of the sampling to the laboratory of Peleforo GON COULIBALY University Health Centre in Korhogo for the blood count.

The blood parameters measured were red blood cells (RBC), packed cell volume (PCV), Hemoglobin ( $\mathrm{Hb})$ and total RBC indices: mean corpuscular volume (MCV), mean corpuscular haemoglobin $(\mathrm{MCH})$, and mean corpuscular haemoglobin concentration (MCHC). Then, total white blood cell WBC count and its differentials (heterophils, lymphocytes, monocytes, eosinophils and basophils). The hemoglobin concentration was determined by the cyanmethaemoglobin method[13] while PCV was estimated by the micro haematocrit method[7]. The RBC and WBC counts were determined using the haemocytometer as described by [14]. The RBC indices were computed using the formulas provided by[15].

\subsection{Statistical Analysis}

For statistical analysis, the data were entered and analysed on STATISTICA software (Windows version 7.1). The mean values of the different hematological parameters in the birds were compared using the non-parametric Mann Whitney $\mathrm{U}$ test. Comparisons of the different proportions obtained of the main blood count parameters were performed by the Loglikelihood ratio test ("G" test) with the statistical software "R" version Windows 2.0.1. The level of 
Vol. 06, No. 02; 2021

ISSN: $2456-8643$

significance was reported at less than $\mathrm{P}<0.05$.

\section{RESULTS}

\subsection{Mean values of hematological parameters}

\subsubsection{Broilers}

The mean values of the different hematological parameters in broilers associated with the standard error on the mean (SEM) are presented in Table 1.Regarding erythrocyte parameters, the mean red blood cell value was $2.89 \pm 0.1 \times 1012 / \mathrm{L}$ with extremes ranging from 1.82 to 4.30 . It was higher in males than in females with a significant difference $(\mathrm{P}<0.05)$. Similarly, the means of hemoglobin and PCV which were $11.06 \pm 0.50 \mathrm{~g} / \mathrm{dL}$ and $28.88 \pm 1.05 \%$ respectively were higher in males than in females with a highly significant and significant difference $(\mathrm{P}<0.001 \& \mathrm{P}<0.05)$. The lower limits were 07.1 and 15.30 and the upper ones were 17.70 and 44.00 for hemoglobin and PCV respectively. However, the other erythrocyte indices (MCV, MCH and MCHC) were higher in males than in females without significant difference. The mean values were $135.12 \pm 5.01 \mathrm{fl}, 39.15 \pm 1.75 \mathrm{pg}$ and $35.38 \pm 8.55 \mathrm{~g} / \mathrm{dL}$ for $\mathrm{MCV}, \mathrm{MCH}$ and $\mathrm{MCHC}$ respectively. Their lower limits were lower than the reference values and conversely the upper limits higher. The mean WBC value, which was $4.59 \pm 0.60 \times 109 / \mathrm{L}$, was higher in males than in females with a significant difference $(\mathrm{P}<0.05)$. The lowest value was below the lower limit of the reference values and the highest was higher than the upper limit. Concerning the other WBC parameters, the mean values for lymphocytes and heterophils were $48.28 \pm 1.73 \%$ and $40.88 \pm 1.75 \%$ respectively. In contrast to lymphocytes, heterophils were higher in females than in males without significant difference. Similarly, eosinophils and basophils are higher in females than in males with no significant difference unlike monocytes. Their respective mean values are $6.31 \pm 0.59 \%$ and $3.69 \pm 0.34 \%$ and $1.47 \pm 0.14 \%$.

\subsubsection{Local chickens}

Table 2 shows the means of the haematological parameters associated with the standard error of the mean. The mean red blood cell value which was $2.89 \pm 0.12 \times 1012 / \mathrm{L}$ was higher in females than in males without significant difference. On the other hand, the haemoglobin level which was $10.43 \pm 0.45 \mathrm{~g} / \mathrm{dL}$ was higher in males than in females with a significant difference $(\mathrm{p}<0.05)$.

Among the erythrocyte indices, MCHC was higher in males $(38.79 \pm 1.49 \mathrm{~g} / \mathrm{dL})$ than in females $(32.91 \pm 2.18 \mathrm{~g} / \mathrm{dL})$ with a very highly significant difference $(\mathrm{p}<0.01)$. All other erythrocyte indices (PCV, MCV and $\mathrm{MCH}$ ) were higher in males than in females without significant difference. Their mean values were $27.39 \pm 1.42 \%, 123.29 \pm 4.33 \mathrm{fl}$ and $38.24 \pm 1.59$ respectively. The mean of white blood cells was $3.00 \pm 0.44 \times 109 / \mathrm{L}$. It was higher in males than in females without significant difference. Similarly, lymphocytes and basophils were higher in males than in females without significant difference. Their mean values are $48.50 \pm 1.80 \%$ and $1.31 \pm 0.08 \%$ respectively. The other leukocyte parameters (heterophil, eosinophil and monocyte) were higher in females than in males without significant difference. Among these leukocyte parameters, heterophils and eosinophils had a mean value greater than the upper limit of the reference values. 
Table 1: Mean values of hematological parameters in broiler chicken

\begin{tabular}{|c|c|c|c|c|c|c|c|c|c|c|c|}
\hline \multirow[t]{2}{*}{ Haematological parameters } & \multicolumn{3}{|c|}{$\begin{array}{l}\text { Total population } \\
\qquad \mathrm{N}=32\end{array}$} & \multicolumn{3}{|c|}{$\begin{array}{l}\text { Male } \\
\mathrm{N}=11\end{array}$} & \multicolumn{3}{|c|}{$\begin{array}{c}\text { Female } \\
\mathrm{N}=21\end{array}$} & \multirow[t]{2}{*}{$\mathrm{p}$ value } & \multirow[t]{2}{*}{$\begin{array}{l}\text { Reference } \\
\text { values [16] }\end{array}$} \\
\hline & Mean \pm SEM & Min & Max & Mean \pm SEM & Min & $\operatorname{Max}$ & Mean \pm SEM & Min & Max & & \\
\hline Red blood cells $\left(10^{12} / \mathrm{L}\right)$ & $2.97 \pm 0.17$ & 1.82 & 4.40 & $3.35 \pm 0.19$ & 2.70 & 4.40 & $2.76 \pm 0.13$ & 1.82 & 4.10 & $0.01(\mathrm{~S})$ & $2.5-3.5$ \\
\hline Hemoglobin (g/dL) & $11.06 \pm 0.50$ & 07.1 & 17.70 & $13.21 \pm 0.95$ & 09.20 & 17.70 & $09.93 \pm 0.41$ & 07.11 & 14.30 & $0.00(\mathrm{~S})$ & $11.0-17.0$ \\
\hline $\mathrm{PCV}(\%)$ & $28.88 \pm 1.05$ & 15.30 & 44.00 & $32.00 \pm 1.87$ & 24.00 & 44.00 & $27.25 \pm 1.13$ & 15.30 & 38.00 & $0.04(\mathrm{~S})$ & $35.0-55.0$ \\
\hline $\operatorname{MCV}(f l)$ & $135.12 \pm 5.01$ & 95.0 & 187.3 & $138.18 \pm 1.69$ & 101.0 & 169.0 & $133.51 \pm 6.59$ & 95.0 & 187.3 & $0.66(\mathrm{NS})$ & $104-140$. \\
\hline $\mathrm{MCH}(\mathrm{pg})$ & $39.15 \pm 1.75$ & 25.00 & 59.00 & $39.39 \pm 4.07$ & 25.00 & 59.00 & $39.03 \pm 1.70$ & 29.00 & 55.00 & $0.18(\mathrm{NS})$ & $33.0-47.0$ \\
\hline $\mathrm{MCHC}(\mathrm{g} / \mathrm{dL})$ & $35.38 \pm 8.55$ & 27.40 & 60.00 & $37.58 \pm 2.16$ & 27.40 & 51.00 & $34.23 \pm 1.60$ & 27.60 & 60.00 & $0.24(\mathrm{NS})$ & $30.2-36.2$ \\
\hline White blood cells $\left(10^{9} / \mathrm{L}\right)$ & $4.59 \pm 0.60$ & 1.06 & 10.20 & $6.27 \pm 0.92$ & 1.26 & 9.91 & $3.71 \pm 0.71$ & 1.06 & 10.20 & $0.04(\mathrm{~S})$ & $1.2-3.0$ \\
\hline Heterophils (\%) & $40.88 \pm 1.75$ & 26.00 & 63.00 & $39.64 \pm 3.11$ & 29.00 & 54.00 & $41.62 \pm 2.16$ & 26.00 & 63.00 & $0.60(\mathrm{NS})$ & $15.0-50.0$ \\
\hline Eosinophils (\%) & $6.31 \pm 0.59$ & 1.00 & 13.00 & $5.82 \pm 1.02$ & 2.00 & 13.00 & $6.57 \pm 0.74$ & 1.00 & 13.00 & $0.45(\mathrm{NS})$ & $1.5-6.0$ \\
\hline Lymphocytes (\%) & $48.28 \pm 1.73$ & 27.00 & 67.00 & $49.82 \pm 3.02$ & 37.00 & 62.00 & $47.48 \pm 2.14$ & 27.00 & 67.00 & $0.88(\mathrm{NS})$ & $45.0-70.0$ \\
\hline Monocytes (\%) & $3.69 \pm 0.34$ & 1.00 & 8.00 & $4.27 \pm 0.73$ & 1.00 & 8.00 & $3.38 \pm 0.36$ & 1.00 & 7.00 & $0.35(\mathrm{NS})$ & $5.0-10.0$ \\
\hline Basophils(\%) & $1.47 \pm 0.14$ & 0.00 & 4.00 & $1.18 \pm 0.12$ & 1.00 & 2.00 & $1.62 \pm 0.20$ & 0.00 & 4.00 & $0.14(\mathrm{NS})$ & Rare \\
\hline Thrombocytes $\left(10^{6} / 1\right)$ & $27.56 \pm 0.51$ & 22.00 & 32.30 & $26.79 \pm 0.60$ & 22.00 & 32.00 & $27.99 \pm 0.45$ & 23.50 & 32.30 & 0.33 (NS & \\
\hline
\end{tabular}

[1]N: Total number of eachsubjects group; MCV: Mean Corpuscular Volume; MCH: Mean corpuscular hemoglobin; MCHC: Mean corpuscular hemoglobin concentration; SEM: Standard error of mean; Min: Minimum; Max: Maximum; S: Statistically differentforpvalue $<0.05$; NS: Not statisticallysignificantforpvalue $<0.05$

Table 2: Mean values of hematological parameters in local chicken

\begin{tabular}{|c|c|c|c|c|c|c|c|c|c|c|c|}
\hline \multirow[t]{2}{*}{ Hematological parameters } & \multicolumn{3}{|c|}{$\begin{array}{l}\text { Total population } \\
\qquad \mathrm{N}=32\end{array}$} & \multicolumn{3}{|c|}{$\begin{array}{l}\text { Male } \\
\mathrm{N}=21\end{array}$} & \multicolumn{3}{|c|}{$\begin{array}{c}\text { Female } \\
\mathrm{N}=10\end{array}$} & \multirow[t]{2}{*}{$\mathrm{p}$ value } & \multirow[t]{2}{*}{$\begin{array}{c}\text { Reference } \\
\text { values [17] }\end{array}$} \\
\hline & Mean \pm SEM & Min & $\operatorname{Max}$ & Mean \pm SEM & Min & $\operatorname{Max}$ & Mean \pm SEM & Min & Max & & \\
\hline Red blood cells $\left(10^{12} / \mathrm{L}\right)$ & $2,89 \pm 0.12$ & 1,87 & 4,20 & $2.95 \pm 0.15$ & 2.10 & 4.20 & $2.73 \pm 0.21$ & 1.87 & 3.90 & $0,40(\mathrm{NS})$ & $2.5-3.5$ \\
\hline Hemoglobin (g/dL) & $10,43 \pm 0.45$ & 6.9 & 15.50 & $10.91 \pm 0.49$ & 6.90 & 14.80 & $09.36 \pm 0.87$ & 6.9 & 15.50 & $0,01(\mathrm{~S})$ & $7.0-13.0$ \\
\hline $\operatorname{PCV}(\%)$ & $27.39 \pm 1.42$ & 12,60 & 46,00 & $27.57 \pm 1.82$ & 12.60 & 46.00 & $26.98 \pm 2.27$ & 21.00 & 45.00 & $0,67(\mathrm{NS})$ & $22.0-35.0$ \\
\hline MCV (fl) & $123,29 \pm 4.33$ & 93,0 & 180,0 & $124.16 \pm 4.71$ & 93.0 & 180.0 & $121.36 \pm 9.62$ & 94.0 & 175.6 & $0,47(\mathrm{NS})$ & $90.0-140$. \\
\hline $\mathrm{MCH}(\mathrm{pg})$ & $38.24 \pm 1.59$ & 24,00 & 59,00 & $38.82 \pm 2.05$ & 24.00 & 59.00 & $36.96 \pm 2.45$ & 26.00 & 50.00 & $0,70(\mathrm{NS})$ & $33.0-47.0$ \\
\hline $\mathrm{MCHC}(\mathrm{g} / \mathrm{dL})$ & $36,95 \pm 1.31$ & 23.90 & 51.00 & $38.79 \pm 1.49$ & 22.70 & 51.00 & $32.91 \pm 2.18$ & 23.90 & 48.30 & $0,00(\mathrm{~S})$ & $26.0-35.0$ \\
\hline White blood cells $\left(10^{9} / \mathrm{L}\right)$ & $3.00 \pm 0.44$ & 1,00 & 10.40 & $2.89 \pm 0.19$ & 1.20 & 5.00 & $2.31 \pm 0.16$ & 1.00 & 3.52 & $0,13(\mathrm{NS})$ & $1.2-3.0$ \\
\hline Heterophils (\%) & $40.44 \pm 1.84$ & 22,00 & 70.00 & $39.97 \pm 2.37$ & 22.00 & 70.00 & $41.5 \pm 2.83$ & 23.00 & 49.00 & $0.18(\mathrm{NS})$ & $15.0-40.0$ \\
\hline Eosinophils (\%) & $7,17 \pm 0.65$ & 1,00 & 14,00 & $6.56 \pm 0.76$ & 1.00 & 13.00 & $8.50 \pm 1.17$ & 3.00 & 14.00 & $0,18(\mathrm{NS})$ & $1.5-6.0$ \\
\hline lymphocytes (\%) & $48.50 \pm 1.80$ & 31,00 & 67,00 & $50.42 \pm 1.88$ & 39.00 & 66.00 & $44.3 \pm 3.85$ & 31.00 & 67.00 & $0,26(\mathrm{NS})$ & $45.0-70.0$ \\
\hline Monocytes (\%) & $4,15 \pm 0.40$ & 0,00 & 9,00 & $4.05 \pm 0.42$ & 2.00 & 9.00 & $4.40 \pm 0.90$ & 0.00 & 9.00 & $0,74(\mathrm{NS})$ & $5.0-10.0$ \\
\hline Basophils(\%) & $1,31 \pm 0.08$ & 1,00 & 2,00 & $1.32 \pm 0.10$ & 1.00 & 2.00 & $1.30 \pm 0.15$ & 1.00 & 2.00 & $0,93(\mathrm{NS})$ & Rare \\
\hline Thrombocytes $\left(10^{6} / 1\right)$ & $29,88 \pm 0.49$ & 24,00 & 33,00 & $30.22 \pm 0.47$ & 24.00 & 34.00 & $29.12 \pm 0.56$ & 24.00 & 32.50 & $0,29(\mathrm{NS})$ & \\
\hline
\end{tabular}

N: Total number of each subjects group; MCV: Mean Corpuscular Volume; MCH: Mean corpuscular hemoglobin; MCHC: Mean corpuscular hemoglobin concentration; SEM: Standard error of mean; Min: Minimum; Max: Maximum; S: Statistically differentforpvalue <0.05; NS: Not statisticallysignificantforpvalue $<0.05$

\subsection{Proportions of the mainerythrocyte parameters in chickens}

The distribution of erythrocyte parameters of all chicken according to international reference standards is presented in Table 3 . According to the results of this table, the pathological level of red blood cell count was higher in broilers (31.25\%) than in local chickens $(28.12 \%)$ without significant difference. On the other hand, the number of chickens with a hemoglobin level below the reference value was higher in broilers $(56.25 \%)$ than in local chickens $(6.25 \%)$ with a very highly significant difference $(\mathrm{p}<0.001)$.

The percentage of local chickens with PCV below 22\% therefore presenting anaemia was $28.13 \%$. This percentage was higher in broilers $(87.50 \%)$ with a highly significant difference $(\mathrm{p}<0.001)$. In contrast, polycythaemia was not observed in broilers while it was $15.62 \%$ in local chickens. The results indicated microcytosis only in broilers. On the other hand, macrocytosis was observed in both groups with a higher rate in broilers (37.50\%) than in local chickens $(25.00 \%)$ without significant difference. Conversely, hypochromia was higher in local chickens (37.50) than in broilers (31.25) with no significant difference. 
Table 3: Proportions of the main erythrocyte parameter in all chicken

\begin{tabular}{|c|c|c|c|c|c|}
\hline \multirow[t]{2}{*}{ Erythrocyte parameters } & \multicolumn{2}{|c|}{$\begin{array}{c}\text { Local Chicken } \\
\mathrm{N}=32\end{array}$} & \multicolumn{2}{|c|}{$\begin{array}{l}\text { Broiler chicken } \\
\qquad \mathrm{N}=32\end{array}$} & \multirow[t]{2}{*}{$\mathrm{p}$ value } \\
\hline & $\mathrm{n}$ & $\%$ & $\mathrm{n}$ & & \\
\hline \multicolumn{6}{|l|}{ Red blood cells $\left(10^{12} / \mathrm{L}\right)$} \\
\hline$<2.5$ & 9 & 28.12 & 10 & 31.25 & $0.68(\mathrm{NS})$ \\
\hline $2.5-3.5$ & 16 & 50.00 & 14 & 43.75 & $0.52(\mathrm{NS})$ \\
\hline$>3.5$ & 7 & 21.88 & 8 & 25.00 & $0.65(\mathrm{NS})$ \\
\hline \multicolumn{6}{|l|}{ Hemoglobin(g/dL) } \\
\hline$<7.0$ and $<11.0$ & 2 & 6.25 & 18 & 56.25 & $1.18 \mathrm{e}^{-11}(\mathrm{~S})$ \\
\hline $7.0-13.0$ and $11.0-17.0$ & 25 & 78.13 & 13 & 40.63 & $0.000(\mathrm{~S})$ \\
\hline$>13.0$ and $>17.0$ & 5 & 15.62 & 1 & 03.12 & $0.002(\mathrm{~S})$ \\
\hline \multicolumn{6}{|l|}{$\operatorname{PCV}(\%)$} \\
\hline$<22.0$ and $<35.0$ & 9 & 28.13 & 28 & 87.50 & $1.55 \mathrm{e}^{-08}(\mathrm{~S})$ \\
\hline $22.0-35.0$ and $35.0-55.0$ & 18 & 56.25 & 4 & 12.50 & $4.07 \mathrm{e}^{-08}(\mathrm{~S})$ \\
\hline$>35.0$ and $>55.0$ & 5 & 15.62 & 0 & 0 & $3.27 \mathrm{e}^{-06}(\mathrm{~S})$ \\
\hline \multicolumn{6}{|l|}{$\mathrm{MCV}(\mathrm{fl})$} \\
\hline$<90.0$ and $<104$ & 0 & 0 & 7 & 21.88 & $3.64 \mathrm{e}^{-08}(\mathrm{~S})$ \\
\hline $90.0-140$ and $104-140$ & 24 & 75.00 & 13 & 40.62 & $0.001(\mathrm{~S})$ \\
\hline$>140$ & 8 & 25.00 & 12 & 37.50 & $0.11(\mathrm{NS})$ \\
\hline \multicolumn{6}{|l|}{$\mathrm{MCH}(\mathrm{pg})$} \\
\hline$<33.0$ & 12 & 37.50 & 10 & 31.25 & $0.45(\mathrm{NS})$ \\
\hline $33.0-47.0$ & 13 & 40.62 & 14 & 43.75 & $0.73(\mathrm{NS})$ \\
\hline$>47.0$ & 7 & 21.88 & 8 & 25.00 & $0.64(\mathrm{NS})$ \\
\hline \multicolumn{6}{|l|}{$\mathrm{MCHC}(\mathrm{g} / \mathrm{dL})$} \\
\hline$<26.0$ and $<30.2$ & 1 & 03.12 & 8 & 25.00 & $1.07 \mathrm{e}^{-05}(\mathrm{~S})$ \\
\hline $26.0-35.0$ and $30.2-36.2$ & 13 & 40.62 & 13 & 40.62 & $1(\mathrm{NS})$ \\
\hline$>35.0$ and $>36.2$ & 18 & 56.25 & 11 & 34.37 & $0.020(\mathrm{~S})$ \\
\hline
\end{tabular}

$\mathrm{N} \& \mathrm{n}$ : Total number of each subjects group; MCV: Mean Corpuscular Volume; MCH: Mean corpuscular hemoglobin; MCHC: Mean corpuscular hemoglobin concentration; S: Statistically different for $\mathrm{p}$ value < 0.05; NS: Not statistically significant for $\mathrm{p}$ value $<0.05$

\subsection{Proportions of main white blood cells in chickens}

Table 4 shows the distribution of the white blood in all chicken. Leukopenia was more observed in broilers (12.50\%) than in local chickens (09.37). Similarly, hyperleukocytosis was higher in broilers compared to local chickens with a significant difference $(p<0.05)$. Heterophilia was much higher in broilers than in local chickens with a significant difference $(p<0.05)$. Monocytopenia was observed in broilers $(65.62 \%)$ than in local chickens $(59.37 \%)$ without significant difference.

Table 4: Proportions of the mainleucocyte parameters in all chicken

\begin{tabular}{|lccccc|}
\hline \multirow{2}{*}{ Leucocyte parameters } & \multicolumn{2}{c}{$\begin{array}{c}\text { cocal Chicken } \\
\mathrm{N}=32\end{array}$} & $\begin{array}{c}\text { Broiler chicken } \\
\mathrm{N}=32\end{array}$ & $\mathrm{p}$ value \\
\cline { 2 - 6 } & $\mathrm{n}$ & $\%$ & $\mathrm{n}$ & & \\
\hline Leucocytes $\left(10^{9} / \mathrm{L}\right)$ & & & & & \\
\hline$<1.2$ & 3 & 09.37 & 4 & 12.50 & $0.50(\mathrm{NS})$ \\
\hline $1.2-3.0$ & 18 & 56.25 & 11 & 34.37 & $0.02(\mathrm{~S})$ \\
\hline
\end{tabular}


Vol. 06, No. 02; 2021

ISSN: $2456-8643$

\begin{tabular}{|lccccc|}
\hline$>3.0$ & 11 & 34.37 & 17 & 53.12 & $0.04(\mathrm{~S})$ \\
\hline Lymphocytes $(\%)$ & & & & & \\
\hline$<45.0$ & 12 & 37.50 & 13 & 40.62 & $0.72(\mathrm{NS})$ \\
\hline $45.0-70.0$ & 20 & 62.50 & 19 & 59.37 & $0.77(\mathrm{NS})$ \\
\hline$>70.0$ & 0 & 0 & 0 & 0 & $1(\mathrm{NS})$ \\
\hline Heterophils (\%) & & & & & \\
\hline$<15.0$ & 0 & 0 & 0 & 0 & $1(\mathrm{NS})$ \\
\hline $15.0-50.0$ & 29 & 90.62 & 25 & 78.12 & $0.33(\mathrm{NS})$ \\
\hline$>50.0$ & 3 & 09.37 & 7 & 21.87 & $0.02(\mathrm{~S})$ \\
\hline Eosinophils (\%) & & & & & \\
\hline$<1.5$ & 3 & 09.37 & 1 & 03.12 & $0.07(\mathrm{NS})$ \\
\hline $1.5-6.0$ & 12 & 37.50 & 17 & 53.12 & $0.09(\mathrm{NS})$ \\
\hline$>6.0$ & 17 & 53.12 & 14 & 43.75 & $0.34(\mathrm{NS})$ \\
\hline Monocytes $(\%)$ & & & & & \\
\hline$<5.0$ & 19 & 59.37 & 21 & 65.62 & $0.57(\mathrm{NS})$ \\
\hline $5.0-10.0$ & 13 & 40.62 & 11 & 34.37 & $0.47(\mathrm{NS})$ \\
\hline$>10.0$ & 0 & 0 & 0 & 0 & $1(\mathrm{NS})$ \\
\hline
\end{tabular}

$\mathrm{N} \& \mathrm{n}$ : Total number of each subjects group; $\mathrm{S}$ : Statistically differentforpvalue $<0.05$; NS: Not statisticallysignificantforpvalue $<0.05$

\section{DISCUSSION}

This prospective study describes the hematological profile of broilers and local chickens sold at the market for consumption in the municipality of Korhogo. The mean values of all hematological parameters in broilers except PCV, white blood cells and eosinophils are within the ranges of the reference values. The mean of PCV is below the lower limit of the reference values. It is also lower than that obtained in the work of $[18,19,20,21]$.

Generally, the decrease in PCV levels suggests the presence of a toxic factor with an adverse effect on haematopoiesis[22]. Nevertheless, the PVC rate is much higher than the value obtained by[23] in their work on broilers. In birds, the PCV value is used to determine anaemia and polycythaemia[24, 25]. The percentage of broilers with anaemia is very high in this study. This high rate is coupled with microcytosis and hypochromia in one third of the broiler population. The hypochromia and microcytosis could indicate a micronutrient deficiency, particularly in iron and vitamins in this broiler population. These deficiencies could be responsible for the observed anaemia. According to the work of [26] iron deficiency is one of the main causes of anaemia. It is known that the main reason for the development of anaemia is dietary[27]. In the present study, the means of red blood cells, haemoglobin and PCV are statistically higher in males than in females. These same observations concerning significantly higher PCV in males than females were made by[28].

White blood cells in birds play an important role in the defence of the body as in mammals and are indicators of the stress response [29]. The proportions of leukocyte parameters of white blood cells give us an indication of the environmental conditions of broilers. The results indicated a high rate of hyperleukocytosis $(53.12 \%)$. In addition, high levels of heterophilia and eosinophils were observed. These results suggest that these birds are under stress and that their response is 
Vol. 06, No. 02; 2021

ISSN: $2456-8643$

reflected in increased heterophilia and leukocytes. Also, allergic or parasitic conditions show increased numbers of eosinophils.

In local chickens, the mean values of all haematological parameters except MCHC and eosinophils were within the ranges of the reference values.

The mean values of red blood cell, haemoglobin and PCV in this study though within the reference ranges are lower than that obtained by[30]in indigenous chickens in Al-hasa, by [31]in Nigerian indigenous chickens, by[32, 33] in local cocks in northern Nigeria. In contrast, the values of MCV, MCH and MCHC in this study are higher than in these two previous studies. This variationin parameters could be explained by the variation in rearing conditions. Indeed, sex, age and diet are the factors that influence haematological parameters in birds[34]as well as altitude[35].

The hemoglobin level was significantly higher in males than in females. The same finding was made by[36]in the Thai indigenous chickens,[37]in Sudan indigenous Chickens, by[38] ,in indigenous chickens in Bangladesh and by[39] in Telangana State Indigenous Chicken. Similarly, the MCHC is significantly higher in males than in females as in the work of $[39,40]$. The percentage of pathological PCV is $28.13 \%$ in these local chickens indicating the presence of anaemia in the third of the population. One quarter of this population had macrocytosis and $37.50 \%$ had hypochromia. Local chickens may have two types of anaemia: hypochromic anaemia, usually due to iron deficiency, and macrocytic anaemia due to deficiency or poor utilisation of vitamin B12 and folate. The mean eosinophil count is above the upper limit of the reference values indicating an increase in eosinophils due to an infectious environment. Thus, there is an increase in the white blood cell count, manifested as hyperleukocytosis.According to[41]the abnormal production of white blood cells in animals is usually associated with an immune response of the animal dueto the presence of an antigen in body.

Furthermore, the mean red blood cell and erythrocyte indices outside of MCHC are higher in broilers than in local chickens. These results are contrary to those obtained by [42]who found higher values in local chickens.

Similarly, apart from red blood cells,[23]found higher means in local chickens. On the other hand, these haematological parameters were higher in broilers than in local chickens in the work of [43] as in this work but with no significant difference apart from the PCV level. Comparing the proportions of the pathological red line parameters, the results indicated a very significantly higher rate of anaemia and microcytosis in broilers than in local chickens. Similarly, for the white line, hyperleukocytosis and heterophilia were significantly higher in broilers than in local chickens. Broilers in this study would be more expose to malnutrition and infections.

\section{CONCLUSION}

The hematological parameters in broilers except PCV, white blood cells and eosinophils and those in local chickens except MCHC and eosinophils were within the ranges of the reference values. They are higher in broilers than in local chickens without significant difference. Furthermore, these values are generally higher in males than in females of the chickens in the study. Anemia and elevated pathological levels of leukocyte parameters indicate malnutrition and an infectious environment on the farms and in the storage areas of the chickens for sale. In view of the differences observed, studies on a larger number of subjects must be undertaken to define the reference haematological parameters of local chickens. 
Vol. 06, No. 02; 2021

ISSN: $2456-8643$

\section{REFERENCES}

[1] Khieu B., (1999). Chicken production, Food Security and Renovative Extension Methodology in the SPFS Cambodia. Conference: Poultry as a tool in Poverty Eradication of Gender Equality. Landbrugets Center for Afteruddannelse, At: http://www.fao.org/docrep/004/ac154e/AC154E09.htm Acces 03mars 2021

[1] FarrellD., (2013). The role of poultry in human nutrition. http://www.fao.org/docrep/013/al709e/ al709e00 Acces 03mars 2021

[2] Rajendran K. and Samarendu M., (2003). Comparative Economic Analysis and Constraints in egg production under cage vs. deep litter systems of rearing in India. International Journal of Poultry Science 2(2) :153-158.

[3] Roberts J.A., (1999). Utilization of Poultry Feed Resources by Smallholders in the Villages of Developing Countries. Poultry as a Tool in poverty Eradication and Promotion of Gender Equality - Proceedings of a Workshop. http://www.husdyr.kvl.dk/htm/php/tune99/28Roberts.htm. Acces 03mars 2021

[4] Brou G.K.G., Adou C.F.D., Kouassi K.D., Diomande D., (2020). Analyse technique de l'élevage du poulet traditionnel en milieu rural dans le département de Dimbokro en Côte d'ivoire, Agronomie Africaine 32 (2) : 121-134

[5] Olafadehan O.A., Olafadehan O.O., Obun C.O., Yusuf A.M., Adewumi M.K., Omotugba S.K. Daniel N.M., (2012). Influence of processing cassava peels on the hydrogen cyanide concentration, nutritive value and performance of growing rabbits. Trop Anim Health Prod 44:285-291.

[6] Jaime S., (2006). "Diagnostic value of haematology". In: Harrison, G.J., Lightfoot T.L. Clinical avian medicine. eds. Spix. Publishing, Palm Beach, FL. pp. 587-609

[7] Harr K.E., (2006). "Diagnostic value of biochemistry". In: Clinical avian medicine. Harrison G.J., and Lightfoot T.L., eds. Spix Publishing, Palm Beach, FL. pp. 611-629.

[8] Kral I. and Suchy P., (2000). Haematological studies in adolescent breeding cocks. Acta Vet. Brno 69: 189-194.

[9] Martin M.P., Wineland M., and Joh H.B., (2010) Selected Blood Chemistry and Gas Reference Ranges for Broiler Breeders Using the i-STAT ${ }^{\circledR}$ Handheld Clinical Analyzer , Avian Diseases 54:1016-1020, 2010.

[10] Ritchie B.W., Harrison J.G. and Harrison R.L., (1994). Avian Medicine, Winger's Publishing, Inc, Florida

[11] Islam M.S., Lucky N.S., Islam M.R., Ahad A., Das B.R., Rahman M.M., and Siddiui M.S.I., (2004). Haematological Parameters of Fayoumi, Assil and Local Chickens Reared in Sylhet Region in Bangladesh. International Journal of Poultry Science 3(2):144-147

[12] Schalm O.W., Jain N.C., and Caroll E.J., (1975). Veterinary haematology, Lea and Febiger, Philadelphia, USA.

[13] Coles E.H., (1986). Veterinary clinical pathology. 4th Ed. W. B. Saunders Company, Philadelphia. USA.

[14] Swenson M.J., (2004). The composition and functions of blood. In: Reece WO (ed). Duke's Physiology of Domestic Animals. 12th ed. Comstock Publishing Associates, Cornell University Press. Ithaca and London. pp 26-51. 
Vol. 06, No. 02; 2021

ISSN: $2456-8643$

[15] Hochleithner M., (2013). Biochemistries. In: Avian medicine online, by Harrison's bird foods: 223-245. www.avianmedicine.net/publication/chapter11- biochemistries/ access $15 / 12 / 2020$

[16] Jain N.C., (1993). Essential of Veterinary Hematology, Lea and Febiger, Philadelphia.417 pages

[17] Abdulazeez H., Adamu S.B., Igwebuike J.U., Gwayo G.J. and Muhammad A.I., (2016). Haematology and Serum Biochemistry of Broiler Chickens Fed Graded Levels of Baobab (Adansonia digitata L.) Seed Meal, IOSR Journal of Agriculture and Veterinary Sciences 9(10):48-53

[18] Ahmed M.AN., (2018). Reference hematology for commercial Ross 308 broilers. Online Journal of Veterinary Research 22 (7):566-570

[19] Talebi A., Asri-Rezaei S., Rozeh-Chai R., Sahraei R., (2005). Comparative Studies on Haematological Values of Broiler Strains (Ross, Cobb, Arbor-acres and Arian), International Journal of Poultry Science 4 (8): 573-579

[20] Saijai K., Peerapol S., Damnern S., (2020). The Study of Hematology in Commercial Broiler Chickens of Cobb 500, Ross 308 , and Arbor Acres Plus. Mahanakorn Vet. Med. 15(2): 209-221

[21] Oyawoye E.O. and Ogunkunle M., (2008). Physiological and biochemical effects of raw jack beans on broilers. Proceedings of Annual Conference of Nigerian Society of Animal Production 23:141-142.

[22] Subhadarsini M., Silpa M.G., (2020). Comparative Haematology And Biochemical Parametrs Of Indigenous And Broiler Chicken. INTERNATIONAL JOURNAL OF SCIENTIFIC \& TECHNOLOGY RESEARCH 9(04):972-979

[23] Duncan J. R., and Prasse K.W.W., (1986). Veterinary laboratory medicine clinical pathology, 2nd ed. Ch. 1: Erythrocytes. Iowa State University Press, Ames, Iowa. pp. 7-9. 1986

[24] Mark A.G, James F.D. and Jonh B., (1992). Packed Cell Volume Reference Intervals to Aid in the Diagnosis of Anemia and Polycythemia in Young Broiler Chicken. AVIAN DISEASES $36: 440-443$

[25] Sean L., Christine M.P., Michael K.G., Gary B., Susan F.T., Richard F.H., Harry J.M.A., and Daniel J.R., (2018). Biomarkers of Nutrition for Development (BOND)-Iron Review. $J$ Nutr 148:1001S-1067S.

[26] Dillon J.C., (2000). Prévention de la carence en fer et des anémies ferriprives en milieu tropical [Prevention of iron deficiency and iron deficiency anemia in tropical areas]. Med Trop 60(1) :83-91

[27] Ghasemi-Sadabadi M., Ebrahimnezhad Y., Maheri-Sis N. and Eshratkhah B., (2018). The effect of different levels of diet total volatile nitrogen on hematological parameters in broiler chickens. J. Livestock Sci. $9: 130-139$

[28] Shaniko S., (2003). Physiological responses of laying hens to the alternative housing systems. Int. J. Poult. Sci. 2: 357-360

[29] Ibrahim A., (2012). Hematological and some biochemical values of indigenous chickens in Al-Ahsa, Saudi Arabia during summer season. Asian J. Poult. Sci. 6(4):138-145 
Vol. 06, No. 02; 2021

ISSN: $2456-8643$

[30] Adeyemo G.O., Bolarinwa M.O., Ehiabhi O., (2018). Hematology and external egg quality parameters of three Nigerian indigenous chicken genotypes. Int J Mol Biol Open Access. 3(4):197-201

[31] Yasks J.A., Momoh M.O. and Dauda A., (2017). Hematological Parameters of three Strains of Local Cocks in Northern Nigeria. International Journal of Environment, Agriculture and Biotechnology (IJEAB) 2(3):1139-1142

[32] Ladokun A.O., Yakubu A., Otite J.R., Omeje J.N., Sokunbi O.A. and Onyeji E., (2008) Haematological and Serum Biochemical Indices of Naked Neck and Normally Feathered Nigerian Indigenous Chickens in a Sub Humid Tropical Environment. International Journal of Poultry Science 7 (1): 55-58

[33] Fudge A.M., (2000). Laboratory medicine: Avian and Exotic Pets. W.B. Saunders company, Philadelphia

[34] Yuan S., Diyan L., Uma G., Binlong C., Xiaoling Z., Yan W., Huadong Y. and Qing Z. (2017): The comparison of blood characteristics in low- and high-altitude chickens, Italian Journal of Animal Science, DOI: 10.1080/1828051X.2017.1355272

[35] Suchint S., Orawan C. and Worapol A., (2004). Hematological, electrolyte and serum biochemical values of the Thai indigenous chickens (Gallus domesticus) in northeastern, Thailand. Songklanakarin J. Sci. Technol. 26(3):426-430

[36] Elagib H.A.A. and Ahmed A.D.A., (2011). Comparative Study on Haematological Values of Blood of Indigenous Chickens in Sudan. Asian Journal of Poultry Science, 5: 4145

[37] Sharmin M.L., and Myenuddin M., (2004). Hematological values of the indigenous chickens. Bangl. J. Vet. Med. 2: 163-164.

[38] Bora S., Gurram S., Sagi R., Tungani R., Kandula S., and Bobbili R., (2017). Effect of Sex on Hematological and Biochemical Parameters in Three Indigenous Chickens in Telangana Region. International Journal of Livestock Research, 7(10):212-218.

[39] Isidahomen E.C, Ozoje M.O. and Njidda A.A., (2011). Haematological and serum biochemical indices of local and exotic chickens in a subhumid tropical environment. Eur. J. Biol. Sci. 3(1): 16-21.

[40] Sowande O.S., Aina A.B.J., Oguntona E.B., Fanimo A.O., Unaka V.U., Itassan T.A., Oseni M.O., (2008). Performance Blood Chemical Constituents and Mineral Balance of West African Dwarf Sheep Fed preserved Elephant Grass, Layer's Droppingsand cassava peel Diet during Dry season. Nig. J. Anim. Prod. 2008: 35 (1): 90-102.

[41] Chinrasri O. and Aengwanich W., (2007). Blood Cell Characteristics, Hematological Values and Average Daily Gained Weight of Thai Indigenous, Thai Indigenous Crossbred and Broiler Chickens. Pakistan Journal of Biological Sciences, 10:302-309

Bahman A.H., Alireza T. and Siamak A.R., (2011). Comparative Study on Blood Profiles of Indigenous and Ross-308 Broiler Breeders. Global Veterinaria 7 (3): 238-24 